\title{
Secondary sex ratio of nestlings of the blackbird (Turdus merula)
}

\author{
PiOTR NOWACKI, ${ }^{1}$ PIOTR PILICZEWSKI, ${ }^{2}$ TOMASZ REK,${ }^{3}$ BEATA KIRIAKA, ${ }^{4}$ \\ DARIUSZ WYSOCKI ${ }^{5}$
}

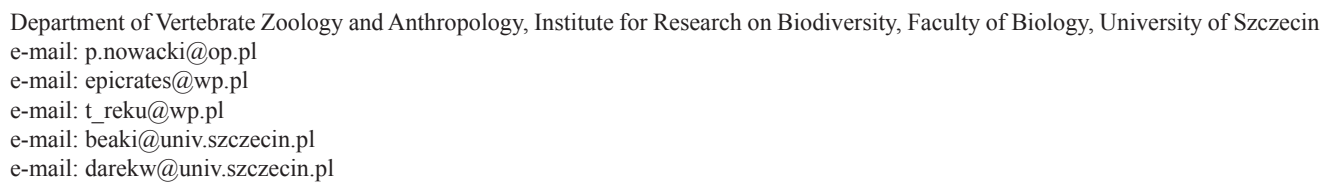

Keywords sex-ratio, blackbird, urban population

Abstract In years 2006-2007 secondary sex ratio of blackbird nestlings in Stefan Żeromski park in Szczecin was studied. 190 nestlings were sexed by genetic analysis. Female: male ratio was found to be $1: 0,94$. No relationships were found between hatching date and sex of nestling and female age and sex of offspring.

\section{Drugorzędowa struktura płciowa u piskląt kosa (Turdus merula)}

Słowa kluczowe struktura płciowa, kos, populacja miejska

Streszczenie W latach 2006-2007 badano drugorzędową strukturę płciową u piskląt kosa w parku im. S. Żeromskiego w Szczecinie. Stosując analizy molekularne oznaczono płeć 190 piskląt. Stosunek samic do samców wynosił $1: 0,94$. Nie stwierdzono zależności między datą wyklucia, a płcią pisklęcia, ani pomiędzy wiekiem samicy, a płcią pisklęcia.

\section{Introduction}

Relative costs and benefits of producing sons and daughters differ across ecological and social environments (Trivers, Willard 1973). Therefore, the potential ability to control offspring sex could have strong fitness consequences (Godfray, Werren 1996; Tagirov, Rutkowska 2013). In birds, proportion of males in a clutch rose correspondingly with their fathers' sexual attractiveness in the collared flycatcher Ficedula albicollis as found by Ellergren et. al. (1996). Tawny owls Strix aluco from the United Kingdom produce a higher percentage of females as a response to high prey availability and quality (Appleby et. al. 1997), but the population in Denmark produces more male chicks in clutches produced during years with high rodent numbers - (Desfor et. al. 2007). In case of the zebra finch Taeniopygia guttata enhancing diet quality appears to increase 
the proportion of males but the results are ambiguous (Rutkowska, Cichon 2002). Male house sparrows Passer domesticus have a higher probability of survival when hatched later in the breeding season and indeed sparrow clutches contain more male chicks as breeding season progresses; this result has a high adaptative value (Husby et. al. 2006) Female common kestrels Falco tinnunculus differentiate offspring sex basing on laying order (Dijkstra et. al.1990), and in american kestrels Falco sparverius sex is largely dependent on egg size (Anderson et al. 1997). Similar relationship has been found in the blackbird Turdus merula (Martyka et. al. 2010).

In our studied population of blackbirds in Szczecin, as in some others, males outnumber females (Stephan 1985, Wysocki 2004, Jarska et. al. 2015), but the reasons behind this disproportion are not clear. It can be an effect of differences in primary sex structure, sex - dependent variance in mortality of embryos and nestlings, or different mortality of adult birds of either sex. Because of high mortality of adult females during egg incubation period (Wysocki, unpubl. data) the last cause is the most probable, but other possible factors should be analyzed as well.

Having exact data about age of females and onset of breeding season in our studied population we tested if female condition affects secondary sex ratio of nestlings. We assumed that females that breed earlier are in better conition than late breeders and that second-year and old females are in lower condition than middle-aged ones (Desrochers 1992a; 1992b; Desrochers, Magrath 1996; Jankowiak, Wysocki 2015). Our base hypothesis however was that female age does not influence sex structure of her offspring.

Although there is a theoretical possibility of sex-based differences in mortality of chicks during incubation or early nestling stage it was not confirmed in rooks Corvus frugilegus although this species has a pronounced sexual dimorphism in size (Orłowski et. al. 2016). Only in one species of bird, Alectura grahami, a member of Megapodidae, differential sex-based mortality in different incubation temperatures was reported (Goth, Booth 2005). However megapodes have a fundamentally different method of incubation than all other birds, some effects of temperature on sex ratio cannot be completely excluded.

\section{Methods}

Fieldwork was conducted daily in early morning hours throughout two full breeding seasons, in 2006 and 2007. Nestlings from which the genetic material was sampled were mostly those from nests built at a height up to $6 \mathrm{~m}$. During removal for ringing (on 8-9th day of life) one growing primary was removed as a tissue sample. Nestlings could therefore be sexed by analyzing the sequences of homologues of CHD1W i CHDIZ as described by Dybus et. al. (2009).

For needs of this analysis, as it was previously stated, we separated the females into two groups. Those with assumed better quality, aged 3 to 5 years and group of presumed lower quality females, birds in their second year and older than 5 years. When analyzing the effect of hatching date on sex of nestlings those hatched until 31st of may were labeled as early clutches and those hatched after this date - late clutches, because this date corresponds well with the median in both years. 


\section{Results}

In 2006 - 108 nestlings belonging to 49 clutches were sexed - 59 as females and 49 as males. In 2007 - 82 nestlings from 30 clutches were sexed - among those we recorded 37 females and 45 males. All nestlings in every clutch were sexed.

Table 1. Percentage of males and females in early and late clutches $(\chi 2=1,41 ; p=0,49)$

\begin{tabular}{|l|c|c|}
\hline & male(n) & female(n) \\
\hline early broods & $47,1 \%(33)$ & $52,9 \%(37)$ \\
\hline late broods & $50,8 \%(61)$ & $49,2 \%(59)$ \\
\hline
\end{tabular}

Table 2. Percentage of males and females in clutches of females of low and high breeding quality $\left(\chi^{2}=0,14\right.$; $\mathrm{p}=0,93)$

\begin{tabular}{|l|c|c|}
\hline & male (n) & female (n) \\
\hline high quality females & $47,4 \%(36)$ & $52,6 \%(40)$ \\
\hline low quality females & $50,9 \%(58)$ & $49,1 \%(56)$ \\
\hline
\end{tabular}

In the studied population offspring sex ratio is not markedly different from 1:1. Observed proportion of females to males are 1:0,94, and all analyzed factors were found to be insignificant.

\section{Discussion}

In general, female quality rises with age. Older females are better in obtaining food, they produce bigger clutches and have longer breeding season (Desrochers 1992a; 1992b; Desrochers, Magrath 1993), and therefore it could be assumed that they should produce a higher proportion of offspring of that sex that has a higher guarantee of passing more genes. Theoretically females in peak breeding condition should invest more in males, that have a higher breeding potential (Clutton-Brock et. al. 1984). Howewer it cannot be excluded that in the studied population males and females have a similar reproductive potential. The care provided by both parents is essential for offspring survival, and attempts at bigamy that are sporadically observed do not raise breeding (Wysocki 2005). A marked increase of female breeding success observed in sequenced polyandry (Wysocki 2004) can level up the effect of sporadic extra-pair copulations observed in males of the highest quality (Wysocki, Hałupka 2004). However it has to be noted that the sample of nestlings was small and research period lasted for only two years. Arbitrary classifying the birds as peak quality breeders based only on age can be also a simplification, even if earlier studies on the same population had shown that this age gives the highest chance of breeding sucess (Zyskowski et. al., in prep.), and in this time blackbirds have the longest wings and lowest asymmetry (Piliczewski et. al. in prep.), and at this age females have the fastest onset of the breeding season. Possibly the best approach in this case would be determining female quality post factum, basing on her breeding success or breeding season length. It is also possible that $50: 50$ sex ratio is actually typical for most birds or populations. Species or populations with skewed sex ratios are sometimes presenting untypical breeding strategies. Other studied populations were breeding in nestboxes, and those may create unnaturally dense or uniformly spaced populations. Similar results to ours were found for example in a savannah sparrow Passerculus sandwichensis 
population (Wheelwright et. al. 2003). Therefore the results we received working on a naturally nesting population of a monogamous species may actually be the norm in a bird world.

\section{References}

Anderson D.J., Reeve J. \& Bird, D.M. 1997. Sexually dimorphic eggs, nestling growth and sibling competition in American kestrels Falco sparverius. Funct. Ecol., 11: 331-335.

Appleby B.M., Petty S.J., Blakey J.K., Rainey P. \& Macdonald D.W. 1997. Does variation of sex ratio enhance reproductive success of offspring in Tawny Owls (Strix aluco)? Proc. R. Soc. Lond. B, 264: $1111-1116$.

Clutton-Brock T.H., Albon S.D. \& Guinness F.E. 1984. Maternal dominance, breeding success and birth sex ratios in red deer. Nature, Lond., 308: 358-360.

Desfor K.B., Boomsma J.J. \& Sunde P. 2007. Tawny Owls Strix aluco with reliable food supply produce male-biased broods. Ibis, 149: 98-105.

Desrochers A., Magrath R.D. 1993. Age-specific fecundity in European blackbirds (Turdus merula): individual and population trends. The Auk, 110 (2): 255-263.

Desrochers A. 1992a. Age-related differences in reproduction by european blackbirds: restraint or constraint. Ecology, 73 (3): 1128-1131.

Desrochers A. 1992b. Age and foraging success in European blackbirds: variation between and within individuals. Anim. Behav., 43: 885-894.

Dijkstra C., Daan S., Buker JB.1990. Adaptive seasonal variation in the sex ratio of kestrel broods. Funct. Ecol., 4: 143-147.

Dybus A., Siemierz A., Wysocki D., Szatkowska I., Muszyńska M., Guenzel S. 2009. Evaluation of the applicability of polymerase chain reaction (PCR) to sex identification in Eurasian blackbirds (Turdus merula). Biological Lett., 46: 17-22.

Ellergren H., Gustaffson L. \& Sheldon B.C. 1996. Sex ratio adjustment in relation to parental attractiveness in a wild bird population. Proceedings of the National Academy of Science USA, 93: 11723-11728.

Godfray H.C.J., Werren J.H.1996. Recent developments in sex ratio studies. Trends in Ecology \& Evolution, 2 (11): 59-63.

Goth A., Booth D.T. 2005. Temperature dependent sex ratio in a bird. Biology Letters, 1: 31-33.

Husby A., Sæther B.-E., Jensen H. \& Ringsby T.H. 2006. Causes and consequences of adaptive seasonal sex ratio variation in house sparrows. Journal of Animal Ecology, 75: 1128-1139.

Jankowiak Ł., Wysocki D. 2015. Do individual breeding experience and parental effort affect breeding season length in blackbirds? Behavioral Ecology, 27 (3): 829-834.

Jarska K., Jankowiak Ł., Śmietana P., Wysocki D. 2015. Blackbirds mate choice: dependence of male social status on age and morphology in an urban population of the European Blackbird, Turdus merula L. Pol. J. Ecol., 63: 448-452.

Martyka R., Rutkowska J., Dybek-Karpiuk A., Cichoń M., Walasz K. 2010. Sexual dimorphism of egg size in the European blackbird Turdus merula. Journal of Ornithology, 151: 827-831.

Orłowski G., Kasprzykowski Z., Czyż B., Zawada Z. 2016. No sex-biased mortality under brood reduction during the early nestling period in the Rook Corvus frugilegus, Ethology, Ecology \& Evolution, 28 (3): $261-271$.

Piliczewski P., Jankowiak Ł., Wysocki D. Wing asymmetry, size and senescence in blackbirds, in prep. 
Rutkowska J., Cichoń M. 2002. Maternal investment during egg laying and offspring sex - an experimental study on zebra finches. Animal Behaviour, 5: 127-132.

Stephan B. 1985. Die Amsel. Neue Brehm-Bucherei 95, Ziensen, Wittenberg Lutherstadt.

Tagirov M., Rutkowska J. 2013.Chimeric embryos - potential mechanism of avian offspring sex manipulation. Behavioral Ecology, 24: 802-805.

Trivers R.L., Willard D.E. 1973. Natural selection of parental ability to vary the sex ratio of offspring. Science, 179: 90-92.

Wheelwright N.T., Seabury R.E., Murphy M. 2003. Fifty : fifty offspring sex ratios in savannah sparrows (Passerculus sandwichensis). The Auk, 1 (120): 171-179.

Wysocki D. 2004. Within-season divorce rate in an urban population of European blackbird Turdus merula. Ardea, 92 (2): 219-228.

Wysocki D. 2005. Alternative mating strategies in urban population of European blackbird Turdus merula . Ardea, 92 (1), 103-112.

Wysocki D., Halupka K. 2004. The frequency and timing of courtship and copulation in blackbirds, Turdus merula, reflect sperm competition and sexual conflict. Behaviour, 141: 501-512.

Zyskowski D., Jankowiak Ł., Wysocki D. Age dependent breeding success of urban population of blackbird, in. prep.

Cite as: Nowacki P., Piliczewski P., Rek T., KiriakaB., Wysocki D. 2016. Secondary sex ratio of nestlings of the blackbird (Turdus merula). Acta Biologica, 23: 69-73. DOI: 10.18276/ab.2016.23-06. 